\title{
Clinical experience in the use of cefuroxime in gonorrhoea
}

\author{
W. FOWLER, G. RAHIM, AND J. D. BROWN \\ From the General Hospital, Birmingham
}

SUMmaRY Cefuroxime, a new antibiotic derived from cephalosporin-C which is very stable in the presence of $\beta$-lactamases produced by Gram-negative organisms, was used to treat 856 male patients and 340 female patients with uncomplicated gonorrhoea. In men the drug was used in three different doses, $1.5 \mathrm{~g}, 1 \mathrm{~g}$, and $750 \mathrm{mg}$ plus $1 \mathrm{~g}$ probenecid; in women $1 \mathrm{~g}$ and $750 \mathrm{mg}$ cefuroxime plus $1 \mathrm{~g}$ probenecid was used. Cure rates ranged from $94.8 \%$ to $99 \cdot 3 \%$. The antibiotic was well tolerated and was free from side effects. Cefuroxime would be a valuable and efficient substitute for penicillin in the treatment of gonorrhoea due to $\beta$-lactamase-producing strains of gonococci.

\section{Introduction}

Cefuroxime is a new antibiotic derived from cephalosporin-C, which is very active against the gonococcus in vitro-much more so than earlier cephalosporins-and is very stable in the presence of $\beta$-lactamases produced by Gram-negative organisms. This latter property is of particular interest in view of the recent appearance of $\beta$-lactamaseproducing strains of gonococci (Phillips, 1976; Ashford et al, 1976) and warranted a clinical trial of cefuroxime in patients with gonorrhoea to see if this antibiotic is as active against the gonococcus in vivo as in vitro.

\section{Materials and methods}

\section{STUDY POPULATION}

Eight hundred and fifty-six male patients and 340 female patients with uncomplicated gonorrhoea were included in the trial. Patients who were pregnant, sensitive to cephalosporins, or under treatment with drugs for other complaints were excluded; otherwise the cases were unselected. Age, racial incidence, and marital state presented no unusual features and need not be given in detail.

\section{DIAGNOSTIC CRITERIA}

Specimens of urethral discharge in men and urethral and cervical discharge in women were Gramstained for microscopical examination and cultured

Address for reprints: Dr W. Fowler, The General Hospital, Steelhouse Lane, Birmingham B4 6NH

Received for publication 10 February 1978 on modified Thayer-Martin medium. In women, culture specimens were also taken from the pharynx and rectum. The diagnosis of gonorrhoea in men was made when both smears and cultures gave positive results in $796(93.1 \%)$ patients, when culture alone gave positive results in $17(1.9 \%)$, and when smears alone gave positive results in $43(5 \%)$.

In women, smears and cultures gave positive results in $196(57.6 \%)$ patients, cultures alone in $100(29.4 \%)$, and smears alone in $44(12.9 \%)$.

Strains of gonococci isolated in culture were tested for sensitivity to penicillin by the disc diffusion method; where there was pronounced resistance the colonies were tested for $\beta$-lactamase production with the chromogenic cephalosporin 87/132.

Minimum inhibitory concentrations (MICs) of cefuroxime were determined in 307 strains of gonococci by the plate dilution method using diagnostic sensitivity agar (Oxoid) containing 5\% horse blood lysed with saponin, and cefuroxime in dilutions varying from $0.007 \mu \mathrm{g} / \mathrm{ml}$ to $1 \mu \mathrm{g} / \mathrm{ml}$.

\section{TREATMENT AND FOLLOW UP}

Cefuroxime was prescribed in three different doses, $1.5 \mathrm{~g}, 1 \mathrm{~g}$, and $750 \mathrm{mg}$ plus $1 \mathrm{~g}$ probenecid. Cefuroxime $1.5 \mathrm{~g}$ was given to $151 \mathrm{men}$ only, cefuroxime $1 \mathrm{~g}$ to $375 \mathrm{men}$ and 204 women, and cefuroxime $750 \mathrm{mg}$ plus probenecid to 330 men and 136 women. The dose of probenecid was given at least 15 minutes before that of cefuroxime.

Cefuroxime was injected intramuscularly and was given before the culture results were known if the microscopical evidence indicated gonorrhoea. Patients were asked to return for follow-up examina- 
tion within two to three days and then at intervals of one, two, four, and six weeks.

Male patients were asked to avoid alcohol and sexual intercourse for at least two weeks after apparent cure and to refrain from micturition for at least two hours before examination. Female patients were asked to avoid alcohol and sexual intercourse until two consecutive follow-up tests for gonococci gave negative results.

At the initial follow-up visit any urethral discharge in male patients was examined by smears and cultures. If there was no obvious discharge, smears and cultures were made from urethral scrapings. At subsequent visits specimens for bacteriological examination were not taken unless the history, clinical examination, or macroscopic appearance of the urine suggested that urethritis was still present.

In female patients, smears and culture specimens were taken from the urethra and cervix at each visit. Culture specimens were also taken from the pharynx and rectum if gonococci had been isolated previously from these sites.

\section{Results}

The number of patients who attended for each follow-up examination and the number of patients with positive results to tests for gonococci at these visits are shown in Tables 1-5. Cultures gave positive results for every patient from whom gonococci were recovered at the first or second follow-up visits. There was a history of exposure to fresh infection for every patient shown in the tables as a 'reinfection'.

Table 6 gives our assessment of the cure rates obtained with the different regimens; there are two rates for each treatment. With both rates, patients with positive results to tests for gonorrhoea at the initial follow-up visit were classified as treatment failures, and patients in whom the gonococcal infection cleared with treatment and then recurred more than 14 days later were classified as having been successfully treated and reinfected.

Table 1 Male patients with gonorrhoea treated with $1.5 \mathrm{~g}$ cefuroxime*

\begin{tabular}{llll}
\hline $\begin{array}{l}\text { Follow-up examination } \\
\text { at }+ \text { (days) }\end{array}$ & $\begin{array}{l}\text { No. of } \\
\text { patients }\end{array}$ & $\begin{array}{l}\text { With positive } \\
\text { gonococcal } \\
\text { isolation }\end{array}$ & Assessment \\
\hline $2-4$ & 128 & 1 & $\begin{array}{l}\text { Treatment } \\
\text { failure }\end{array}$ \\
$9-14$ & 87 & 4 & $\begin{array}{l}\text { Reinfection } \\
\text { Reinfection } \\
\text { Reinfection } \\
\text { Reinfection }\end{array}$ \\
$35-48$ & 59 & 4 & \\
$49-60$ & 26 & 5 & \\
\hline *A total of 151 patients & 15 & 2 & \\
†A total of 128 patients followed up &
\end{tabular}

Table 2 Male patients with gonorrhoea treated with $1 \mathrm{~g}$ cefuroxime*

\begin{tabular}{|c|c|c|c|}
\hline $\begin{array}{l}\text { Follow-up } \\
\text { examination at } \dagger \\
\text { (days) }\end{array}$ & $\begin{array}{l}\text { No. of } \\
\text { patients }\end{array}$ & $\begin{array}{l}\text { With positive } \\
\text { gonococcal } \\
\text { isolation }\end{array}$ & Assessment \\
\hline $\begin{array}{l}2-4 \\
9-14\end{array}$ & $\begin{array}{l}335 \\
253\end{array}$ & $\begin{array}{l}4 \\
4\end{array}$ & $\begin{array}{l}\text { Treatment failure } \\
\text { Treatment failure } \\
\text { (1 patient) } \\
\text { Reinfection } \\
\text { (3 patients) }\end{array}$ \\
\hline $\begin{array}{l}19-28 \\
35-48 \\
49-90\end{array}$ & $\begin{array}{r}164 \\
75 \\
45\end{array}$ & $\begin{array}{l}5 \\
8 \\
6\end{array}$ & $\begin{array}{l}\text { Reinfection } \\
\text { Reinfection } \\
\text { Reinfection }\end{array}$ \\
\hline
\end{tabular}

*A total of 375 patients

†A total of 335 patients followed up

Table 3 Female patients with gonorrhoea treated with 1 g cefuroxime*

\begin{tabular}{llll}
\hline $\begin{array}{l}\text { Follow-up } \\
\text { examination at } \dagger \\
\text { (days) }\end{array}$ & $\begin{array}{l}\text { No. of } \\
\text { patients }\end{array}$ & $\begin{array}{l}\text { With positive } \\
\text { gonococcal } \\
\text { isolation }\end{array}$ & Assessment \\
\hline $2-4$ & 184 & 4 & Treatment failure \\
$9-14$ & 154 & 3 & $\begin{array}{l}\text { Reinfection } \\
\text { (1 patient) } \\
\text { Treatment failure } \\
\text { (2 patients) } \\
\end{array}$ \\
& 103 & 3 & $\begin{array}{l}\text { Reinfection } \\
\text { Reinfection } \\
\text { Reinfection }\end{array}$ \\
$35-28$ & 48 & 3 & Rein \\
$49-90$ & 19 & 5 & \\
\hline
\end{tabular}

*A total of 204 patients

$\dagger$ A total of 184 patients followed up

Table 4 Male patients with gonorrhoea treated with $750 \mathrm{mg}$ cefuroxime plus $1 \mathrm{~g}$ probenecid*

\begin{tabular}{|c|c|c|c|}
\hline $\begin{array}{l}\text { Follow-up } \\
\text { examination at } \dagger \\
\text { (days) }\end{array}$ & $\begin{array}{l}\text { No. of } \\
\text { patients }\end{array}$ & $\begin{array}{l}\text { With positive } \\
\text { gonococcal } \\
\text { isolation }\end{array}$ & Assessment \\
\hline $\begin{array}{l}2-4 \\
9-14\end{array}$ & $\begin{array}{l}292 \\
201\end{array}$ & $\begin{array}{r}1 \\
11\end{array}$ & $\begin{array}{l}\text { Treatment failure } \\
\text { Treatment failure } \\
\text { (1 patient) } \\
\text { Reinfection } \\
\text { (10 patients) }\end{array}$ \\
\hline $\begin{array}{l}19-28 \\
35-48 \\
49-90\end{array}$ & $\begin{array}{r}103 \\
59 \\
25\end{array}$ & $\begin{array}{l}3 \\
6 \\
3\end{array}$ & $\begin{array}{l}\text { Reinfection } \\
\text { Reinfection } \\
\text { Reinfection }\end{array}$ \\
\hline
\end{tabular}

*A total of 330 patients

†A total of 292 patients

Table 5 Female patients with gonorrhoea treated with $750 \mathrm{mg}$ cefuroxime plus $1 \mathrm{~g}$ probenecid*

\begin{tabular}{lcll}
\hline $\begin{array}{l}\text { Follow-up } \\
\text { examination at } \dagger \\
\text { (days) }\end{array}$ & $\begin{array}{l}\text { No. of } \\
\text { patients }\end{array}$ & $\begin{array}{l}\text { With positive } \\
\text { gonococcal } \\
\text { isolation }\end{array}$ & Assessment \\
\hline $2-4$ & 117 & 2 & Treatment failure \\
$9-14$ & 104 & 4 & Reinfection \\
$19-28$ & 50 & - & Reinfection \\
$35-48$ & 30 & 2 & Reinfection \\
$49-90$ & 9 & 4 & \\
\hline
\end{tabular}

*A total of 136 patients

$\dagger A$ total of 117 patients followed up 
The other patients, those with negative results to tests at the first follow-up visit and positive results at the second, were assessed in two ways:

1. All patients were regarded as treatment failures.

2. Patients were regarded as treatment failures if there was no history of fresh exposure to infection and as having been reinfected if there was such a history.

The first of these assessments was made in the light of the thesis by Willcox (1964) that all such cases could be relapses and the second in accordance with the criterion adopted by Lynn et al (1970). The true rate of cure falls somewhere between the two rates given in Table 6 .

Table 6 Cure rates in patients with gonorrhoea treated with cefuroxime

\begin{tabular}{lll}
\hline Dosage & Men (\%) & Women (\%) \\
\hline Cefuroxime & $96 \cdot 2-99 \cdot 3$ & - \\
$1.5 \mathrm{~g}$ & $97 \cdot 6-98 \cdot 5$ & $96 \cdot 1-97 \cdot 8$ \\
$1 \mathrm{~g}$ & $95 \cdot 8-99.6$ & $94 \cdot 8-98 \cdot 2$ \\
$750 \mathrm{mg}$ plus & probenecid $1 \mathrm{~g}$ & 9 \\
\hline
\end{tabular}

POSTGONOCOCCAL URETHRITIS

The incidence of postgonococcal urethritis was $15.6 \%$ (20 cases) with cefuroxime $1.5 \mathrm{~g}, 16.5 \%$ (54 cases) with cefuroxime $1 \mathrm{~g}$, and $15.4 \%$ (45 cases) with cefuroxime $750 \mathrm{mg}$ plus probenecid $1 \mathrm{~g}$.

\section{SENSITIVITY TO PENICILLIN AND}

CEFUROXIME

None of the 1137 strains of gonococci isolated showed any unusual degree of resistance to penicillin, and none produced $\beta$-lactamase.

The MICs of cefuroxime are shown in Table 7. Unfortunately, these were determined in only three cases of treatment failure (in the largest series) and were $0.25 \mu \mathrm{g} / \mathrm{ml}$ in two cases and $0.03 \mu \mathrm{g} / \mathrm{ml}$ in the other.

Table 7 Sensitivity of gonococci to cefuroxime

\begin{tabular}{|c|c|c|c|}
\hline \multirow{2}{*}{$\begin{array}{l}M I C \\
(\mu g / m l)\end{array}$} & \multicolumn{2}{|c|}{ No. of strains } & \multirow[b]{2}{*}{$\%$} \\
\hline & Men & Women & \\
\hline $\begin{array}{l}0.007 \\
0.015 \\
0.03 \\
0.06 \\
0.12 \\
0.25 \\
\text { Total }\end{array}$ & $\begin{array}{r}63 \\
53 \\
37 \\
38 \\
13 \\
8 \\
212\end{array}$ & $\begin{array}{r}37 \\
18 \\
14 \\
11 \\
6 \\
9 \\
95\end{array}$ & $\begin{array}{r}32 \cdot 3 \\
23 \cdot 2 \\
16 \cdot 7 \\
16 \cdot 0 \\
6 \cdot 2 \\
5 \cdot 6\end{array}$ \\
\hline
\end{tabular}

\section{SIDE EFFECTS}

Local

The intramuscular injection of cefuroxime produced little local discomfort.

\section{Systemic}

Urticaria developed within 48 hours of the injection in two out of the 1196 patients treated. Both patients were treated with $1 \mathrm{~g}$ cefuroxime. One, a female patient, gave a history of sensitivity to the tetracyclines and some other antibiotics but not to penicillin, and the other, a male patient, did have a history of penicillin sensitivity and it might have been wiser to exclude him from the trial.

\section{Discussion}

Sufficient patients have been treated in this trial to show that cefuroxime in the dosage used is as highly effective against the gonococcus in vivo as in vitro. The drug was well tolerated and remarkably free from side effects. Because of its stability in the presence of $\beta$-lactamases cefuroxime will be a valuable and efficient substitute for penicillin in the treatment of gonorrhoea due to $\beta$-lactamase-producing strains of gonococci.

We are grateful to the staff of Glaxo Research Ltd, in particular to Mrs B. M. Mullinger for providing the antibiotic.

\section{References}

Ashford, W. A., Golash, R. G., and Hemming, V. G. (1976). Penicillinase-producing Neisseria gonorrhoeae, Lancet, 2, 637-658.

Lynn, R., Nicol, C. S., Ridley, M., Rimmer, D., Symonds, M. A. E., and Warren, C. (1970). Further studies of penicillin resistant gonococci. British Journal of Venereal Diseases, 46, 404-405.

Phillips, I. (1976). Beta-lactamase-producing penicillin-resistant gonococcus. Lancet, 2, 656-657.

Willcox, R. R. (1964). Ampicillin by injection and by mouth in the treatment of acute gonorrhoea. British Journal of Venerea Diseases, 40, 261-265. 